\title{
THE ROLE OF HEALTH BELIEFS IN COVID-19 PREVENTIVE BEHAVIOR
}

The study was supported by the Science Committee of RA, in the frames of the research project №20TTSH-070:

Manusyan S.H., Hakobjanyan A. R. (Yerevan State University, Yerevan, Armenia)

s_manusyan@ysu.am,a_hakobjanyan@ysu.am

乙tipluјugर्ume uर्u. 31.07.2021

9pmpunuर्ume uर्u. 03.09.2021

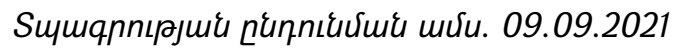

Beliefs have proved to be significant factors in regulating behavior, including health-related behaviors. The health belief model suggests that people can perform or change their behavior depending on their perceptions of health and disease. The present study discusses the health beliefs underlying Covid-19 preventive behaviors.

The study objectives were to identify the predictive significance of healthrelated beliefs in COVID-19 preventive behavior as well as to content-wise interpret the specifics of some COVID-19-related beliefs and self-reported behavior. The sample comprised 237 participants (64,1\% female, $M=29,75$; $\mathrm{SD}=10,693$; Range=18-58), regression analysis was performed. Some results of in-depth interviews on COVID-19 perceptions (conducted as part of the project's qualitative component) were thematically analyzed and used in interpreting the statistical data. According to the results, preventive behaviors such as frequent hand washing or disinfection of frequently used objects, infrequent leaving the house, wearing a mask, avoiding meeting friends and relatives are conditioned by beliefs about the effectiveness of preventive behavior, perceived barriers and perceived severity. The predictive significance of beliefs for COVID-19 preventive behaviors suggests that their further identification and scrutiny can contribute to the improvement and promotion of individuals' preventive behaviors both in times of the pandemic and other large-scale healthcare issues.

Keywords: Covid-19, preventive behavior, health beliefs, health behavior, regression analysis.

DOI: https://doi.org/10.46991/SBMP/2021.4.2.229

Introduction: Health beliefs and behavior

Health and disease research presently defines wider, multidimensional healthcare issues. At the core of this multidimensionality is the research on beliefs - human understandings and perceptions of and attitudes towards health and 
disease. Beliefs are the basis for manifest behavior; hence understanding of health behaviors requires the study of the underlying cognitions $[3,4]$.

Health behavior is generally defined as actions that individuals and groups engage in that affect their health in positive or negative ways, and that form the basis for developing coping strategies and social and strategic change programs and improving the quality of life. "Healthy behavior" includes such personality characteristics as beliefs, expectations, motivations, values, perceptions, personality factors, emotional states and traits as well as those overt behaviors - habits and actions - that pertain to maintaining, attaining or regaining good health. Preventive behavior is one of the three health behavior types alongside illness behavior and sick-role behavior identified by KasI\&Cobb (cited by [2]). It implies any activity that a person undertakes to protect themselves from potential harm (e.g. using seatbelts while driving, using masks in case of infections spreading by airborne transmission etc.) [2].

The leading approach explaining health behavior is the health belief model developed by Hochbaum and colleagues in the 1950s in an effort to explain failures in the preventive measures in the U.S. public healthcare system, in particular the low efficiency of programs aimed at early detection and prevention of tuberculosis [5]. According to the model, the degree of willingness of a person to engage in any health-related activity is the result of the perceived threat or harm of the disease. This perception is in turn formed from the following components: perceived susceptibility to the disease, perceived severity, perceived benefits, perceived barriers, cues to action and self-efficacy. The latter two constructs were added later as the model evolved [7, 9].

Perceived severity of the disease refers to a person's beliefs about the seriousness of the course and/or the consequences of an illness [6]. Perceived susceptibility refers to a person's subjective evaluation of the risk of getting ill or infected, and is the most sensitive belief component in terms of malleability to change and shaping of a more healthy behavior. The higher the perceived risk of acquiring the illness, the greater the chance that the behavior will be revised to a healthier one aimed at the risk reduction. However, the construct has its reverse side too: the lower the perceived risk for oneself, the quicker the development of unhealthy behaviors [5, 6]. Perceived benefits refer to a person's evaluation of the effectiveness of various actions available to reduce the threat of disease/illness and to form new behaviors aimed at maintaining, attaining or improving health. Perceived barriers are a person's evaluations of all those obstacles that stand in the way of developing a new, healthier behavior [5]. The cue to action is the stimulus that triggers the health-related decision-making process; cues can be both internal (such as pain symptoms) or external (media information or misinformation, 
precautions, advice etc.). And finally, self-efficacy is about a person's confidence in performing effective preventive behaviors [6, 9].

From its initial development to this day, the model continues to be the most common basis for social-psychological investigations into health behavior [4, 7]. It has gained new momentum in the context of the COVID-19 pandemic and the difficulties that various countries have been facing in achieving preventive behavior among the population [10]. The perceptions of and behavioral responses to the COVID-19 pandemic posed quite a challenge in many societies, thus prompting series of (cross-) cultural health belief and behavior studies. Admittedly, all of the above discussed beliefs acquired relevance, meaning and content also in Armenia. They mattered especially during the first wave of the pandemic when the general uncertainty around the disease and the official regulation attempts were confronting the prevailing lay understandings and behavior patterns related to infectious diseases and healing, which hardly prioritized science-recommended prevention. Instead, refutations of the disease severity, susceptibility and effectiveness of preventive measures were commonplace and were extensively promoted through media misinformation flows throughout the pandemic1.

Method and sample: The present study aims at identifying the predictive significance of health-related beliefs in COVID-19 preventive behavior as well as content-wise interpreting some COVID-19-related beliefs and self-reported behavior.

The data were collected online during the period of May-June 2020 ("first wave") from in total 237 recruited participants (64,1\% female, $M=29,75$; $\mathrm{SD}=10,693$; Range=18-58): $41,4 \%$ of the sample has higher education (Master degree or above), $62,4 \%$ is employed, $82,3 \%$ was not infected with coronavirus as of the survey. The study participants have estimated their economic status (1=much below the average, $7=$ much higher than the average) mainly as slightly higher than average $(M=4,44 ; S D=1,132)$. These demographic data were used as controlled variables in the analysis.

The following measures were used:

1. The modification of Health Belief Scale by Champion [3] tailored to measuring coronavirus-related beliefs [8]. The tool comprises 20 items evaluated on a scale of 1-7 (1-definitely disagree - 7 strongly agree) and measures 5 factors:

1 Thus, a freshly published report on "Four Main Topics Of Misinformation In Armenia" features misinformation surrounding Covid-19 as one of the four most manipulated and falsified grand themes with political motivations behind.

See https://media.am/en/newsroom/2021/07/12/28865/, accessed on 01.08.2021, 10:55 pm. 
- Chance: measures a person's conviction regarding the plausibility of getting infected with the coronavirus. The factor has an internal consistency of $\alpha=0,648$.

- Severity: measures a person's belief about the negative impact of the coronavirus. The factor's internal consistency is $\alpha=0,760$.

- Gaining prevention: identifies a person's belief about the significance of preventive actions against the coronavirus. The internal consistency equaled $\alpha=0,535$.

- Efficacy prevention: measures a person's confidence in the effectiveness of own preventive actions. The factor had an internal consistency of $\alpha=0,630$.

- Barriers: Refers to the perceived obstacles for various preventive actions. The factor has an internal consistency of $\alpha=0,494$ :

2. The measure "Behaviors" developed specifically for behaviors associated with the pandemic [8] and constructed from 3 behavior types: preventive (staying at home, disinfection, frequent hand washing, searching for information), hoarding (stockpiling food, hygiene and protective products) and helping (assisting physically and psychologically). The internal consistency indices for each behavior type are 0,733,0,713 and 0,607 respectively.

3. Fear of COVID-19 Scale: The tool is intended for measuring a person's fear associated with the coronavirus and the pandemic [1]. Participants indicate their agreement with each statement according to Likert scale (1 for total disagreement to 7 for complete agreement). The measure had internal consistency of $\alpha=0,891$.

Discussion and conclusions: To identify the predetermining significance of health beliefs for behaviors initiated in response to the COVID-19-driven situation, hierarchical regressison analysis was performed'. The following sequence of independent variables was selected: some demographical data (age, gender, education, employement and economic statuses, infectedness with coronavirus) as controlled variables at the first level; health beliefs at the second level and fear of COVID-19 at the third level. The regression model was constructed individually for each behavior type, maintaining the above-indicated sequence in all the models. The following predictors were identified for preventive behaviors.

For the behavior "frequent hand washing or decontaminating of frequently touched places and objects", efficacy prevention beliefs $(B=0,233 ; p<0,0001)$ and

1 The indicator of variables multicollinearity was tested in advance for substantiated choice of the regression method. VIF (variance inflation factor) was taken as a criterion, whose value falls within acceptable range $(>1<10)$ for the examined variables. 
fear of COVID-19 ( $B=0,162 ; p=0,02)$ proved to be of determining significance: One interpretation of this relationship is that the greater one's fear of COVID-19 and simultaneously one's confidence in the effectiveness of own preventive steps, the more pronounced the aforementioned behavior will be. The explanatory power of the regression model is $24,5 \%(F=5,968 ; p<0,0001)$ : To be sure, this relationship was revealed during the first wave of the pandemic, whereas the perceived effectiveness of this behavior might have well been revised during the later periods of the pandemic in the country. This is demonstrated by observations of especially those interview participants who, despite their compliance with that recommended behavior (as well as with wearing a mask) in the early stages of the outbreak, did later contract the coronavirus at the backdrop of high COVID-19 rates and poor oversight for preventive requirements, which altogether compromised the value of individual efforts.

- "Limiting leaving home without explicit necessity" behavior had as its predictive factors the age $(B=-0,013 ; p=0,045)$, employment $(B=-0,286 ; p=0,048)$, education $(B=0,461 ; p=0,003)$, and beliefs of chance $(B=-0,140 ; p=0,05)$ and efficacy prevention $(B=0,171, p=0,010)$. This picture of predictive factors indicates that this behavior tends to be opted and considered as helpful in reducing the chance of contracting the virus by younger (the age factor has the reverse direction) people when they are simultaneously unemployed (as of the survey), have higher education, and are convinced in the effectiveness of own preventive actions. The regression model has an explanatory power of $23,1 \%(F=5,611 ; p<0,0001)$. These data too, resonate with the picture drawn from in-depth interviews, in which conscious self-restriction of movements (mainly out of concerns over infecting their elderly family members if being out frequently) was reported by the younger respondents, who at the same time characterized this restriction as psychologically the most challenging one. As a possible explanation to why unemployment played in this model, it might be due to the simple fact that movement restriction is easier to follow for those who don't have permanent job requiring workplace attendance.

- For "avoiding meeting family and friends" behavior, beliefs of severity $(B=0,261 ; p=0,001)$, efficacy prevention $(B=0,139 ; p=0,045)$ and perceived barriers $(B=-0,165 ; p=0,024)$ have shown predictive significance. It can be argued that beliefs in the severity are also manifested in concerns for the health of the dear ones, leading to avoidance of meeting them, which in turn is assessed as an effective behavior for infection prevention. The explanatory power of the regression model is $22,4 \%$ ( $F=5,433 ; p<0,0001)$. Infrequent meeting with loved ones was mentioned as "very difficult yet necessary" by most interview participants regardless of their age group (young adults or the middle-aged) but mainly among those with higher education. 
- For the behavior labeled "wearing a mask outside", the following belief factors had predictive significance: gaining prevention $(B=0,166 ; p=0,019)$ and barriers $(B=-0,231 ; p=0,004)$, so that the lower the perception of barriers (such as the widespread arguments that masks compromise oxygen level and are harmful that were used to avoid wearing them), the greater the plausibility of this behavior. The model's explanatory power is $16,5 \% \quad(F=4,404$; $p<0,0001)$.

This brief analysis illustrates how health beliefs play a remarkable role in behavioral choices related to COVID-19 prevention. As the results of the regression analysis suggest, for various COVID-19 preventive behaviors, prevention beliefs anchored in self-efficacy have a particular role.

Armenia has been falling behind - both in the initial and later stages of the pandemic - in acquiring knowledge based on psychological evidence and using it to improve prevention messaging. Nonetheless, ongoing research aimed at a more nuanced examination of beliefs (and their socio-cultural factors) underlying health behavior remains highly relevant in the present context of poor vaccination rates, since the results can inform public awareness efforts in the desired direction.

\section{References}

1. Ahorsu, D. K., Lin, C. Y., Imani, V., Saffari, M., Griffiths, M. D., \& Pakpour, A. H. The Fear of COVID-19 Scale: Development and Initial Validation. International journal of mental health and addiction, 2020, pp.19. doi:10.1007/s11469-020-00270-8.

2. Breslow L. (ed) Encyclopedia of Public Health, Macmillan Reference USA, 2002, 1480p. doi:10.1007/978-1-4020-5614-7.

3. Champion, V.L., Skinner, C. S. The health belief model. Health behavior and health education: Theory, research, and practice, 4, 2008, pp. 45-65. ISBN 978-0-7879-9614-7

4. Forshaw M. Essential Health Psychology, Oxford University Press, 2002, 236p. ISBN 9780340759714.

5. Hochbaum G. Rosenstock I. \& Kegels S. Health belief model. United states public health service, W432W8784, 1952. https://doi.org/10.1177/109019817400200405.

6. Janz N., Becker M. The Health Belief Model: A Decade Later, Health $\begin{array}{lllll}\text { Education } \quad \text { Quarterly, } \quad \text { Vol.11, 1984, } & \text { pp. } & \text { 1-47. }\end{array}$ DOI: 10.1177/109019818401100101.

7. Nemcek, M.A. Health beliefs and preventive behavior: a review of research literature. Aaohn Journal 38, no. 3. 1990: pp. 127-138. https://doi.org/10.1177/216507999003800306. 
8. Nowak, B., Brzóska, P., Piotrowski, J., Sedikides, C., ŻemojtelPiotrowska, M., \& Jonason, P. K. Adaptive and maladaptive behavior during the COVID-19 pandemic: The roles of Dark Triad traits, collective narcissism, and health beliefs. Personality and Individual Differences 167, 2020, pp. 110-232. https://doi.org/10.1016/j.paid.2020.110232.

9. Redding C. A., Rossi J. S., Rossi S. R., Velicer W. F., Prochaska J. O. Health Behavior Models. The International Electronic Journal of Health Education, N 3 (Special Issue), 2000, pp. 180-193. http://www.iejhe.siu.edu.

10. Sarwar, F., Panatik, S. A., \& Sarwar, F. Editorial: Psychology of Preventive Behavior for COVID-19 Outbreak. Journal of Research in Psychology, 2 (1), 2020, pp. 1-3. DOI:10.31580/jrp.v2i1.1370.

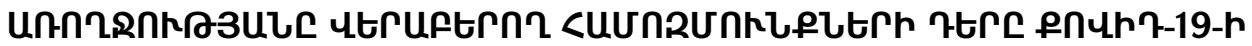 4UutuURQthL2 чurenkU}

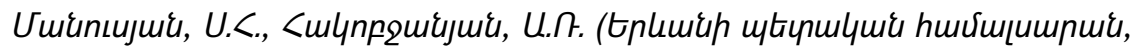
tpluши, <щјмичми)

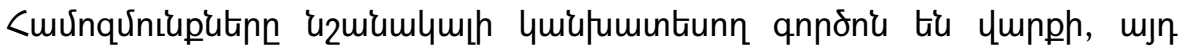

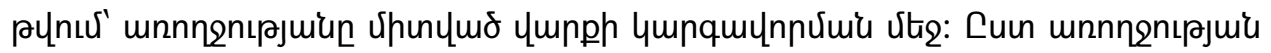

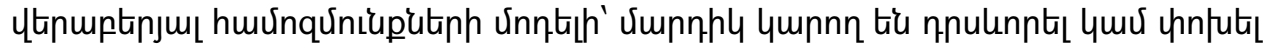

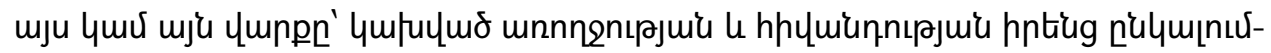

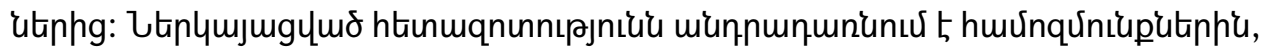

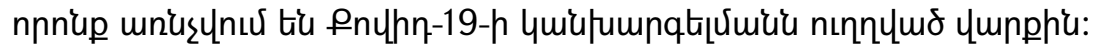

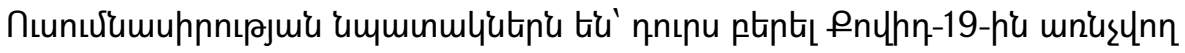

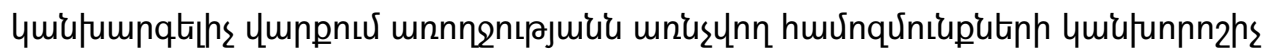

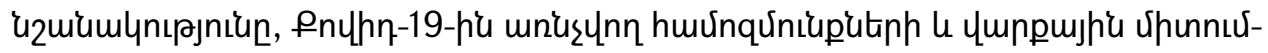

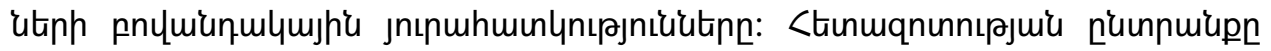

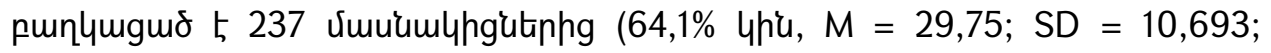

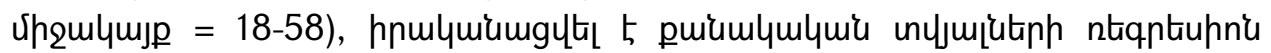

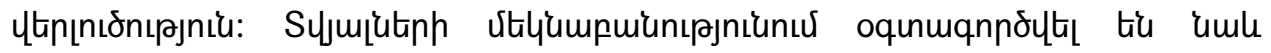

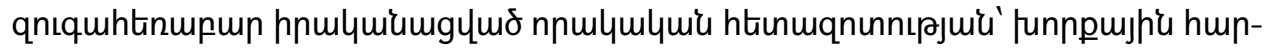

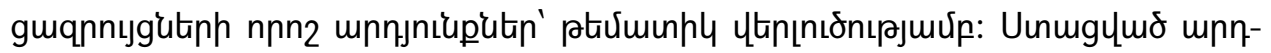

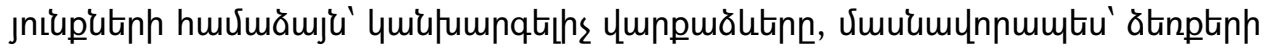

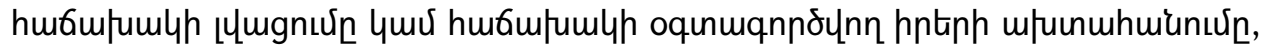

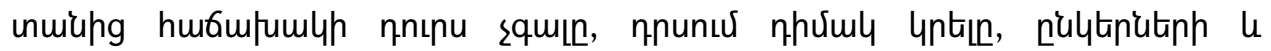

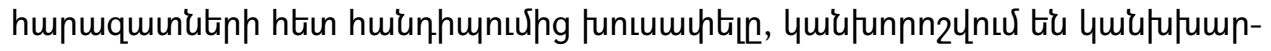

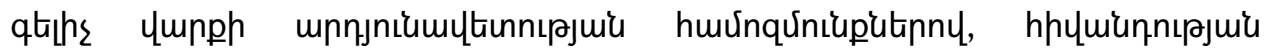

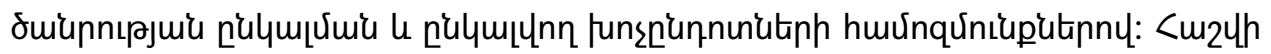

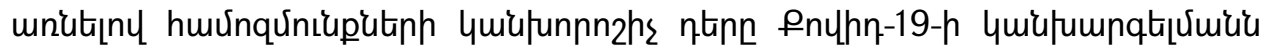




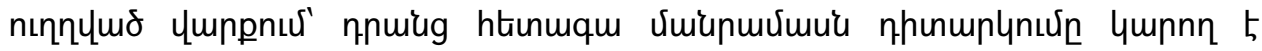

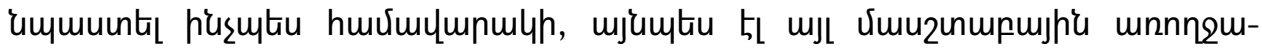

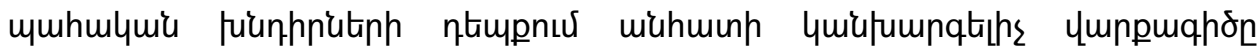

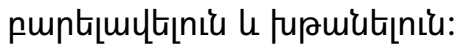

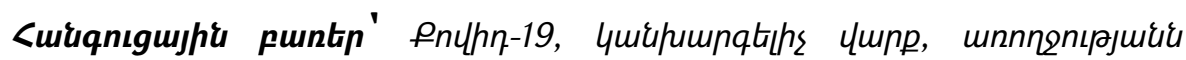

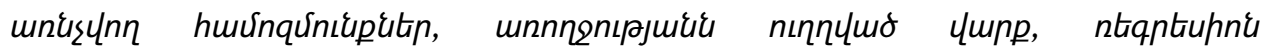

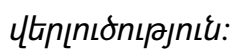

\title{
РОЛЬ УБЕЖДЕНИЙ В ОТНОШЕНИИ ЗДОРОВЬЯ В ПРЕВЕНТИВНОМ ПОВЕДЕНИИ СВЯЗАННЫМ С COVID-19
}

\author{
Манусян С.О., Акопджанян А. Р. (Ереванский государственный \\ университет, Ереван, Армения)
}

Убеждения являются значимыми фракторами в регуляции поведения, в том числе поведения, связанного со здоровьем. Модель убеждений в отношении здоровья предполагает, что люди могут осуществлять или изменять свое поведение в зависимости от их представлений о здоровье и болезни. В настоящем исследовании рассматриваются убеждения в отношении здоровья, связанные с профилактическим поведением COVID-19.

Целями исследования были определение прогностической ценности убеждений отношении здоровья в превентивном поведении COVID-19, а также рассмотрение содержательных особенностей некоторых убеждений, связанных с COVID-19. Выборка состояла из 237 участников (64,1\% жен, $M=29,75$; $\mathrm{SD}=10,693$; Range=18-58), был проведен регрессионный анализ. Некоторые результаты глубинных интервью о восприятии COVID-19 (проведенных в рамках качественного компонента проекта) были тематически проанализированы и использованы при интерпретации данных. Согласно полученным результатам, такие формы превентивного поведения, как частое мытье рук или дезинфекция часто используемых предметов, нечастый выход из дома, ношение маски, избегание встреч с друзьями и родными, обусловлены убеждениями об эффрективности собственного превентивного поведения, воспринимаемой тяжестью и барьерами. Прогностическая ценность убеждений для поведения COVID-19 указывает, что их дальнейшее изучение может способствовать улучшению и поощрению превентивного поведения, как во время пандемии, так и при решении других масштабных проблем здравоохранения.

Ключевые слова: Covid-19, превентивное поведение, убеждения в отношении здоровья, поведение в отношении здоровья, регрессионный анализ. 